\title{
ポリマーセメントモルタルの耐透水性及び耐久性に及ぼす ポリマー混入率の影響
}

出村克宣 ${ }^{* 1}$ 齋藤俊克 ${ }^{* 1}$ 武田昌也 ${ }^{* 2}$

*1 日本大学 工学部建築学科 (

*2 日本大学 大学院工学研究科建築学専攻 (T963-8642 福島県郡山市田村町徳定字中河原 1)

\begin{abstract}
要旨: 本研究ではポリマーセメントモルタルの耐透水性及び耐久性に及ばすポリマー混入率の影響につい て検討している。その結果、水セメント比、ポリマー混入率、空気量及び細骨材セメント比を考慮したポ リマーセメントモルタルの透水量、中性化深さ及び塩化物イオン浸透深さ影響因子を提案している。これ らの影響因子とポリマー未混入モルタルの透水量、中性化深さ及び塩化物イオン浸透深さの積から、ポリ マーセメントモルタルの透水量、中性化深さ及び塩化物イオン浸透深さが推定でき、その一般式を提案す ると共に、ポリマーセメントモルタルの新規な調合要因としてポリマー混入率を取り扱うことができるこ とを明らかにしている。
\end{abstract}

キーワード：ポリマーセメントモルタル、ポリマー混入率、透水量、中性化深さ、塩化物イオン浸透深さ、 影響因子、推定式

\section{1. はじめに}

一般にポリマーセメントモルタル(以下 PCM)の性能 は、セメントに対するセメント混和用ポリマーの全固形 分の質量比であるポリマーセメント比(以下 $\mathrm{P} / \mathrm{C}$ )を指 標として検討されることが多い。これは、PCM の各種 性状が P/C に依存することによるものである。しかし、 同一 $\mathrm{P} / \mathrm{C}$ であっても、例えばセメント砂比が異なる場 合には性状が異なるため、PCM の性状を P/C で一義 的にとらえることが困難な場合がある。従って、PCM を複合材料としてとらえ、基材となるセメントモルタル 中のポリマー連続相を指標とするような調合因子を見 いだす必要があると考える。そこで既往の研究に抒い て1, 2)、PCM の総体積に占めるポリマー固形分の体積分 率を「ポリマー混入率(又は単位ポリマー量)」と定義し、 PCM の吸水及び強さ性状はポリマー混入率で評価でき ることを見いだしている。

本研究では、PCM の耐透水性並びに耐久性の指標と しての中性化及び塩化物イオン浸透抑制に及ぼすポリ マー混入率の影響について検討し、新規な調合要因とし てのポリマー混入率について考察している。

\section{2. 使用材料}

\section{1 セメント及び細骨材}

セメントとしてはJIS R 5210(ポルトランドセメント) に規定されている普通ポルトランドセメント、細骨材と しては阿武隈川産川砂、練混ぜ水としては上水道水を使 用した。それらの性質を Table 1 及び Table 2 に示す。

\section{2 セメント混和用ポリマー}

セメント混和用ポリマーとしてはノニオン系及びカ チオン系アクリル酸エステル共重合樹脂(それぞれ、 PAE-N 及び PAE-C と略称する)を使用した。それら の性質を Table 3 に示す。

\section{3 消泡剂}

消泡剂としてはシリコーン系粉末消泡剤を、セメント 混和用ポリマーの全固形分に対して $3 \%$ 添加して使用 した。

Table 1 Physical Properties and Chemical Compositions of Ordinary Portland Cement

\begin{tabular}{|c|c|c|c|c|c|c|}
\hline & \multirow{2}{*}{$\begin{array}{c}\text { Blaine } \\
\text { Density } \\
\left(\mathrm{g} / \mathrm{cm}^{3}\right)\end{array}$} & $\begin{array}{c}\text { Specific } \\
\text { Surface } \\
\left(\mathrm{cm}^{2} / \mathrm{g}\right)\end{array}$ & \multicolumn{2}{|c|}{$\begin{array}{c}\text { Setting Time } \\
(\mathrm{h}-\mathrm{min})\end{array}$} & \multicolumn{3}{|c|}{$\begin{array}{c}\text { Compressive } \\
\text { Strength of Mortar } \\
(\mathrm{MPa})\end{array}$} \\
\cline { 3 - 7 } & $\begin{array}{c}\text { Snitial } \\
\text { Set }\end{array}$ & $\begin{array}{c}\text { Final } \\
\text { Set }\end{array}$ & $3 \mathrm{~d}$ & $7 \mathrm{~d}$ & $28 \mathrm{~d}$ \\
\hline \hline 3.16 & 3300 & $2-01$ & $3-15$ & 30.2 & 46.1 & 62.4 \\
\hline \hline \multicolumn{6}{|c|}{ Chemical Compositions (\%) } \\
\hline $\mathrm{MgO}$ & $\mathrm{SO}_{3}$ & ig.loss & \multicolumn{2}{|c|}{ Total Alkali } & Chloride Ion \\
\hline \hline 1.73 & 2.05 & 1.69 & 0.54 & 0.023 \\
\hline
\end{tabular}

Table 2 Properties of Fine Aggregate

\begin{tabular}{|c|c|c|}
\hline $\begin{array}{c}\text { Size } \\
(\mathrm{mm})\end{array}$ & $\begin{array}{c}\text { Density } \\
\left(\mathrm{g} / \mathrm{cm}^{3}\right)\end{array}$ & $\begin{array}{c}\text { Water Absorption } \\
(\%)\end{array}$ \\
\hline \hline$\leqq 2.5$ & 2.66 & 2.09 \\
\hline
\end{tabular}




\section{3. 試験方法}

\section{1 供試体の作製}

JIS A 1171(PCM の試験方法)に準じて細骨材セメン 卜比 $(\mathrm{S} / \mathrm{C})$ を 2 及び 3、水セメント比 $(\mathrm{W} / \mathrm{C})$ を $45 \%$ 一 定、ポリマー混入率を $0 、 2 、 4$ 及び $6 \%$ とした調合の 供試 PCM を練混ぜ、フロー值及び空気量を測定した。 但し練混ぜ時の調合においては空気量を考慮していない ため、測定された空気量を加味して算出した PCM の体 積分率による調合を Table 4 に示す。

更に、練混ぜた供試 PCM を寸法 $\phi 150 \times 40 \mathrm{~mm}$ (透水 量試験用供試体)及び、寸法 $100 \times 100 \times 400 \mathrm{~mm}$ (促進中 性化試験及び塩化物イオン浸透試験用供試体)に成形し た後、次に示す養生を行って各供試体を作製した。

a) 標準養生 (W5D21) : $2 \mathrm{~d}$ 湿空 $\left[20{ }^{\circ} \mathrm{C} 、 90 \%(\mathrm{RH})\right] 、 5 \mathrm{~d}$ 水中 $\left(20{ }^{\circ} \mathrm{C}\right)$ 及び $21 \mathrm{~d}$ 乾燥 $\left[20{ }^{\circ} \mathrm{C} 、 60 \%(\mathrm{RH})\right]$

b) 乾燥養生(D26)：2d 湿空 $\left[20^{\circ} \mathrm{C} 、 90 \%(\mathrm{RH})\right]$ 及び $26 \mathrm{~d}$ 乾燥 $\left[20^{\circ} \mathrm{C} 、 60 \%(\mathrm{RH})\right]$

なお、作製した促進中性化試験及び塩化物イオン浸透 試験用供試体については、養生終了 $3 \mathrm{~d}$ 前にコンクリー トカッターを用いて寸法 $100 \times 100 \times 100 \mathrm{~mm}$ になるよう に切断し、切断面とその相対する側面、打込み面及び底 面の 4 面をエポキシ樹脂塗料でシールした。

\section{2 空気量試験}

JIS A 1171 に従って供試PCMの空気量試験を行った。

\section{3 透水量試験}

JIS A 1171 に従って、作製した供試体を $80{ }^{\circ} \mathrm{C}$ の乾燥 機で $48 \mathrm{~h}$ 乾燥させ、デシケーター内で泠却してから透 水量試験を行い、次式により透水量を算出した。

Table 3 Properties of Redispersible Polymer Powder for Cement Modifier

\begin{tabular}{|c|c|c|c|c|}
\hline $\begin{array}{c}\text { Type of } \\
\text { Polymer }\end{array}$ & $\begin{array}{c}\text { Density } \\
\left(\mathrm{g} / \mathrm{cm}^{3}\right)\end{array}$ & $\begin{array}{c}\text { Glass- } \\
\text { Transition } \\
\text { Temp., Tg } \\
\left({ }^{\circ} \mathrm{C}\right)\end{array}$ & $\begin{array}{c}\text { Non- } \\
\text { Volatile } \\
\text { Matter } \\
(\%)\end{array}$ & $\begin{array}{c}\text { Type } \\
\text { of } \\
\text { Charge }\end{array}$ \\
\hline \hline PAE-N & 0.50 & 8 & $99 \pm 1$ & Non-ion \\
\hline PAE-C & 0.50 & 8 & $99 \pm 1$ & Cation \\
\hline
\end{tabular}

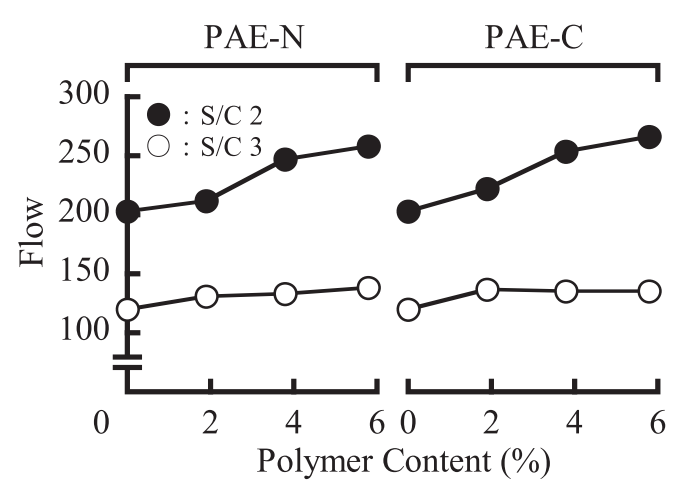

Fig. 1 Polymer Content vs. Flow of PolymerModified Mortars

$$
\begin{aligned}
W_{p}=W_{1}- & W_{0} \\
\text { ここに、} & W_{p}: \text { 透水量 }(\mathrm{g}) \\
& W_{0}: \text { 乾燥後の供試体の質量 }(\mathrm{g}) \\
& W_{1}: \text { 透水後の供試体の質量 }(\mathrm{g})
\end{aligned}
$$

\section{4 促進中性化試験及び塩化物イオン浸透試験}

JIS A 1171 に従って促進中性化試験用供試体を、 $30{ }^{\circ} \mathrm{C} 、 60 \%(\mathrm{RH}) 、 \mathrm{CO}_{2}$ 濃度 $5.0 \%$ の $\mathrm{CO}_{2}$ 環境槽内に 静置し、又、塩化物イオン浸透深さ試験用供試体を JIS A 6205 (鉄筋コンクリート用防せい剂) の附属書 1 (鉄筋 の塩水浸せき試験方法)の 3.2 .1 (塩分溶液)に規定する 塩分溶液に浸せきし、それぞれ 28、56d 間促進中性化 試験及び塩化物イオン浸透試験を行った。

\section{4. 試験結果及び考察}

Fig. 1 には PCM のフロー值とポリマー混入率の関係 を示す。セメント混和用ポリマーの種類にかかわらず、 S/C 2 の PCM のフロー值はポリマー混入率の増加に伴 い増大し、S/C 3 の PCM のフロー值はポリマー混入率 が増加してもほぼ一定值を与える傾向にある。このこと は一般に、セメント混和用ポリマーの持つ界面活性効果 やポリマー粒子のボールベアリング効果によって PCM の流動性が改善される傾向にあるが、その改善効果はセ メント量の多いものが優れることを示唆するものである。

Fig. 2 には PCM の空気量とポリマー混入率の関係を 示す。セメント混和用ポリマーの種類及び $\mathrm{S} / \mathrm{C}$ にかか

\begin{tabular}{|c|c|c|c|c|c|c|c|c|}
\hline \multirow{2}{*}{$\begin{array}{l}\text { Type of } \\
\text { Polymer }\end{array}$} & \multirow{2}{*}{$\mathrm{S} / \mathrm{C}$} & \multirow{2}{*}{$\begin{array}{l}\mathrm{W} / \mathrm{C} \\
(\%)\end{array}$} & \multicolumn{5}{|c|}{$\begin{array}{c}\text { Mix Proportions by Volume } \\
(\%)^{*}\end{array}$} & \multirow{2}{*}{$\begin{array}{l}\mathrm{P} / \mathrm{C} \\
(\%)\end{array}$} \\
\hline & & & $\mathrm{P}$ & $\mathrm{C}$ & $\mathrm{S}$ & $\mathrm{W}$ & Air & \\
\hline \multirow{8}{*}{ PAE-N } & \multirow{4}{*}{2} & \multirow{8}{*}{45} & 0 & 19.7 & 48.4 & 28.1 & 3.7 & 0 \\
\hline & & & 1.9 & 19.4 & 47.5 & 27.5 & 3.5 & 3.3 \\
\hline & & & 3.8 & 18.9 & 46.2 & 26.8 & 4.0 & 6.8 \\
\hline & & & 5.8 & 18.6 & 45.4 & 26.3 & 3.7 & 10.3 \\
\hline & \multirow{4}{*}{3} & & 0 & 15.3 & 56.0 & 21.6 & 6.7 & 0 \\
\hline & & & 1.9 & 15.1 & 55.0 & 21.2 & 6.4 & 4.1 \\
\hline & & & 3.9 & 14.6 & 53.6 & 20.7 & 6.7 & 8.4 \\
\hline & & & 5.7 & 14.3 & 52.5 & 20.3 & 6.5 & 12.9 \\
\hline \multirow{8}{*}{$\mathrm{PAE}-\mathrm{C}$} & \multirow{4}{*}{2} & \multirow{8}{*}{45} & 0 & 19.7 & 48.4 & 28.1 & 3.7 & 0 \\
\hline & & & 1.9 & 19.2 & 47.1 & 27.3 & 4.2 & 3.3 \\
\hline & & & 3.9 & 18.9 & 46.4 & 26.9 & 3.7 & 6.8 \\
\hline & & & 5.7 & 18.4 & 44.9 & 26.0 & 4.5 & 10.3 \\
\hline & \multirow{4}{*}{3} & & 0 & 15.3 & 56.0 & 21.6 & 6.7 & 0 \\
\hline & & & 1.9 & 15.1 & 55.3 & 21.3 & 5.9 & 4.1 \\
\hline & & & 3.8 & 14.8 & 54.3 & 21.0 & 5.6 & 8.4 \\
\hline & & & 5.7 & 14.5 & 53.3 & 20.6 & 5.4 & 12.9 \\
\hline
\end{tabular}
わらず、ポリマー未混入モルタル $(\mathrm{P} / \mathrm{C}: 0 \%)$ と比べて、 ポリマー混入率の増加に伴い S/C 2 の PCM の空気量

Table 4 Mix Proportions of Polymer-Modified Mortars

Note, * P : Polymer, C : Cement, S : Sand, W : Water 
は若干減少し、S/C 3 のもののそれはほぼ一定值を示す 傾向にある。一般にセメント混和用ポリマーは空気連行 性を有しており、本研究ではその全固形分に対して $3 \%$ 一定の消泡剂を添加している。そのため、ポリマー混入 率が増加すれば PCM の単位容積中の消泡剂量が増加す るが、空気連行性と消泡効果の相乗効果が空気量に現れ るものと推察される。

Fig. 3 から Fig. 5 には PCM の透水量、中性化深さ

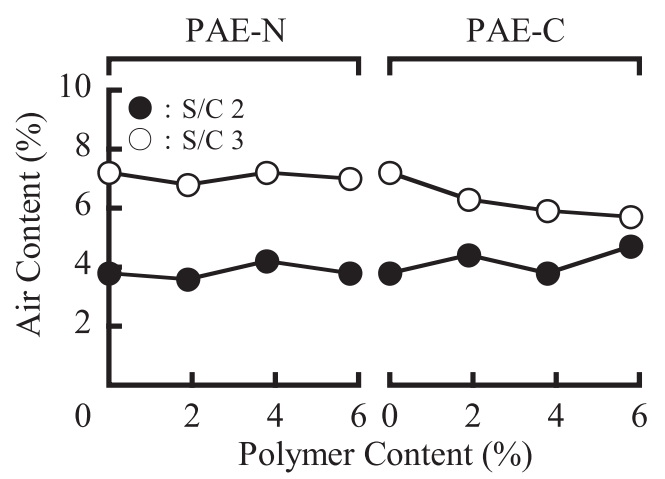

Fig. 2 Polymer Content vs. Air Content of PolymerModified Mortars
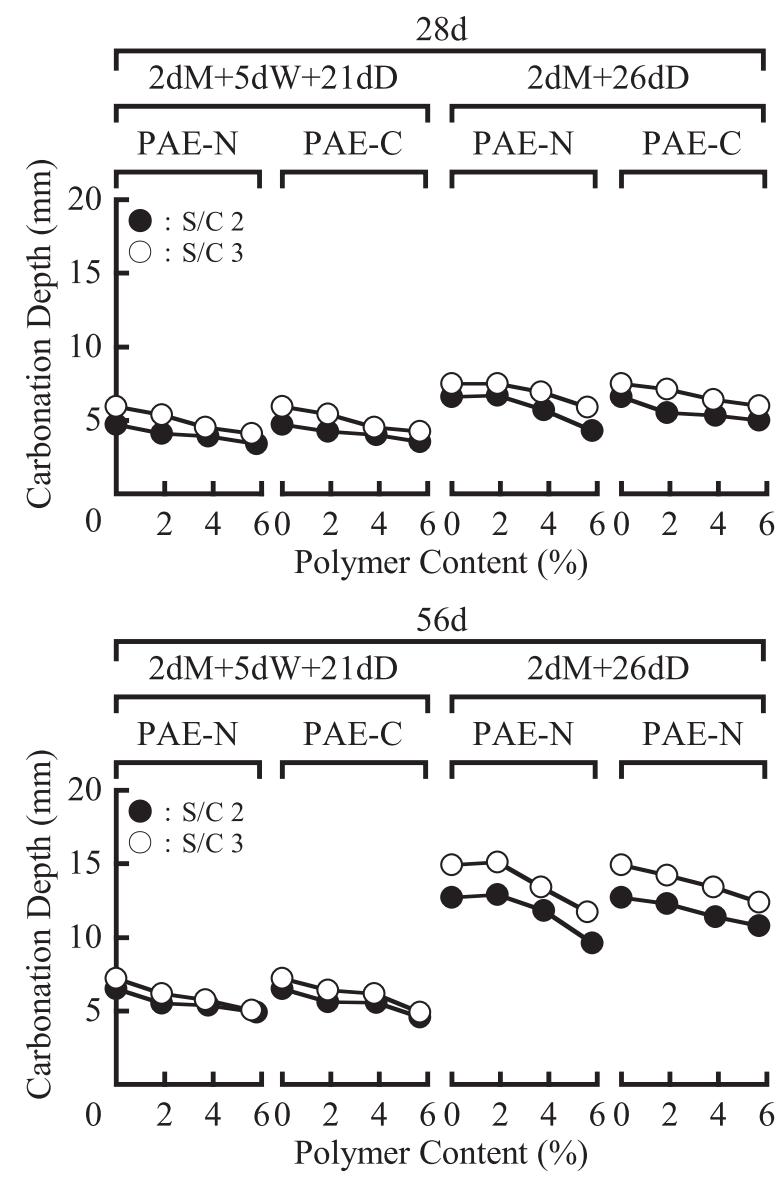

Fig. 4 Polymer Content vs. Carbonation Depth of Polymer-Modified Mortars
及び塩化物イオン浸透深さとポリマー混入率の関係を示 す。セメント混和用ポリマーの種類、S/C 及び養生条 件にかかわらず、ポリマー混入率の増加に伴って PCM の透水量、中性化深さ及び塩化物イオン浸透深さは減少 する。これは、ポリマー混入率の増加に伴い PCM 中に 形成されるフィルム状や糸状のポリマー連続相が増加し て、水や $\mathrm{CO}_{2}$ の浸入に対するバリア効果が向上するた めと推察される。なお、養生条件及びポリマー混入率に

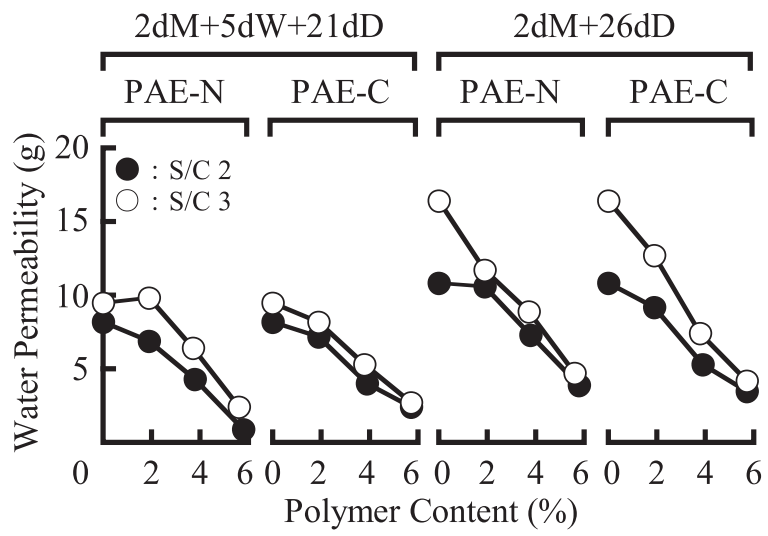

Fig. 3 Polymer Content vs. Water Permeability of Polymer-Modified Mortars
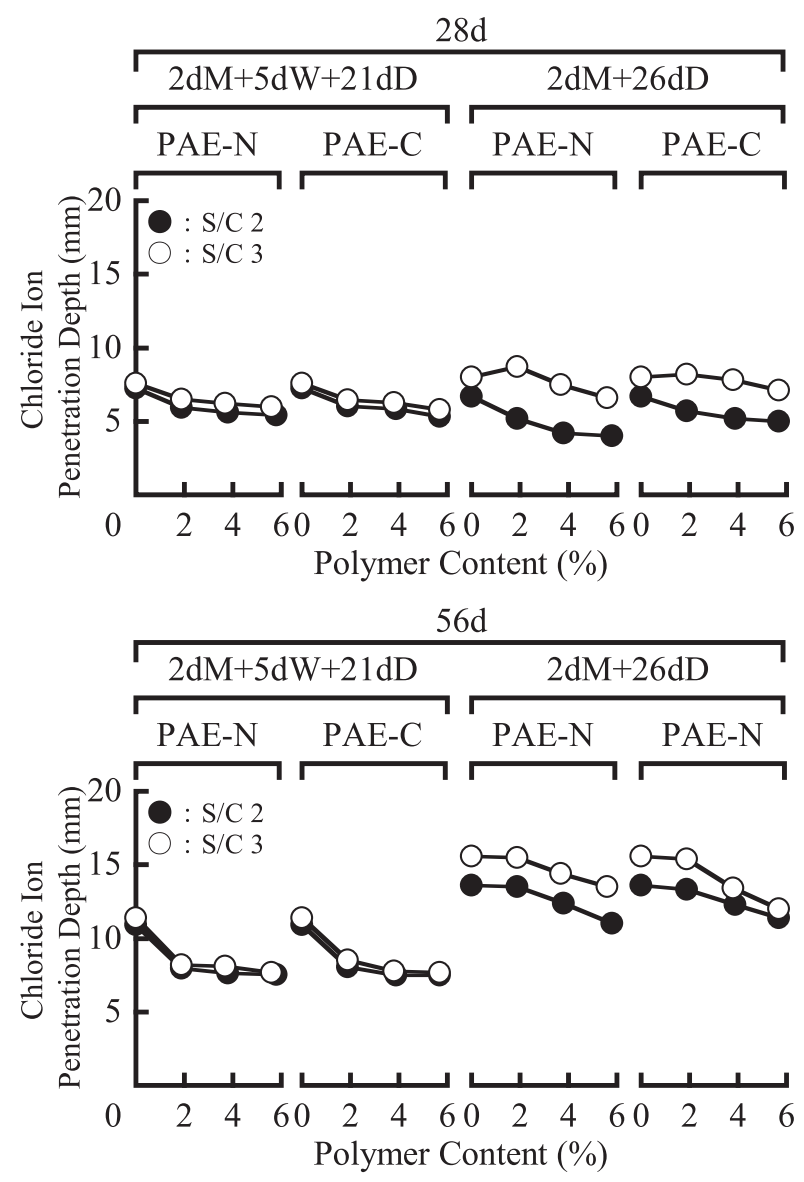

Fig. 5 Polymer Content vs. Chloride Ion Penetration Depth of Polymer-Modified Mortars 
かかわらず、S/C 2 の PCM に比べて S/C 3 のものの 透水量、中性化深さ及び塩化物イオン浸透深さは若干大 きい傾向にある。これは、いずれの養生条件においても、 ポリマー未混入モルタルのそれらが $\mathrm{S} / \mathrm{C} 2$ のものに比 べて S/C 3 のものが大きいことによるものと考える。 しかし、ポリマー混入率の増加に伴うそれらの低減の程 度は、S/Cにかかわらずほぼ同様の傾向にある。従って、 基材となるセメントモルタルの調合にかかわらず、ポリ
マー連続相のバリア効果はポリマー混入率に依存するこ とが示唆される。

Fig. 6 及び Fig. 7 には PCM の中性化深さ及び塩化物 イオン浸透深さとそれらの試験期間の関係を養生条件別 に示す。PCM の中性化深さ及び塩化物イオン浸透深さ と促進中性化及び塩化物イオン浸透試験期間の関係は、 次のような一般式で表すことができる。

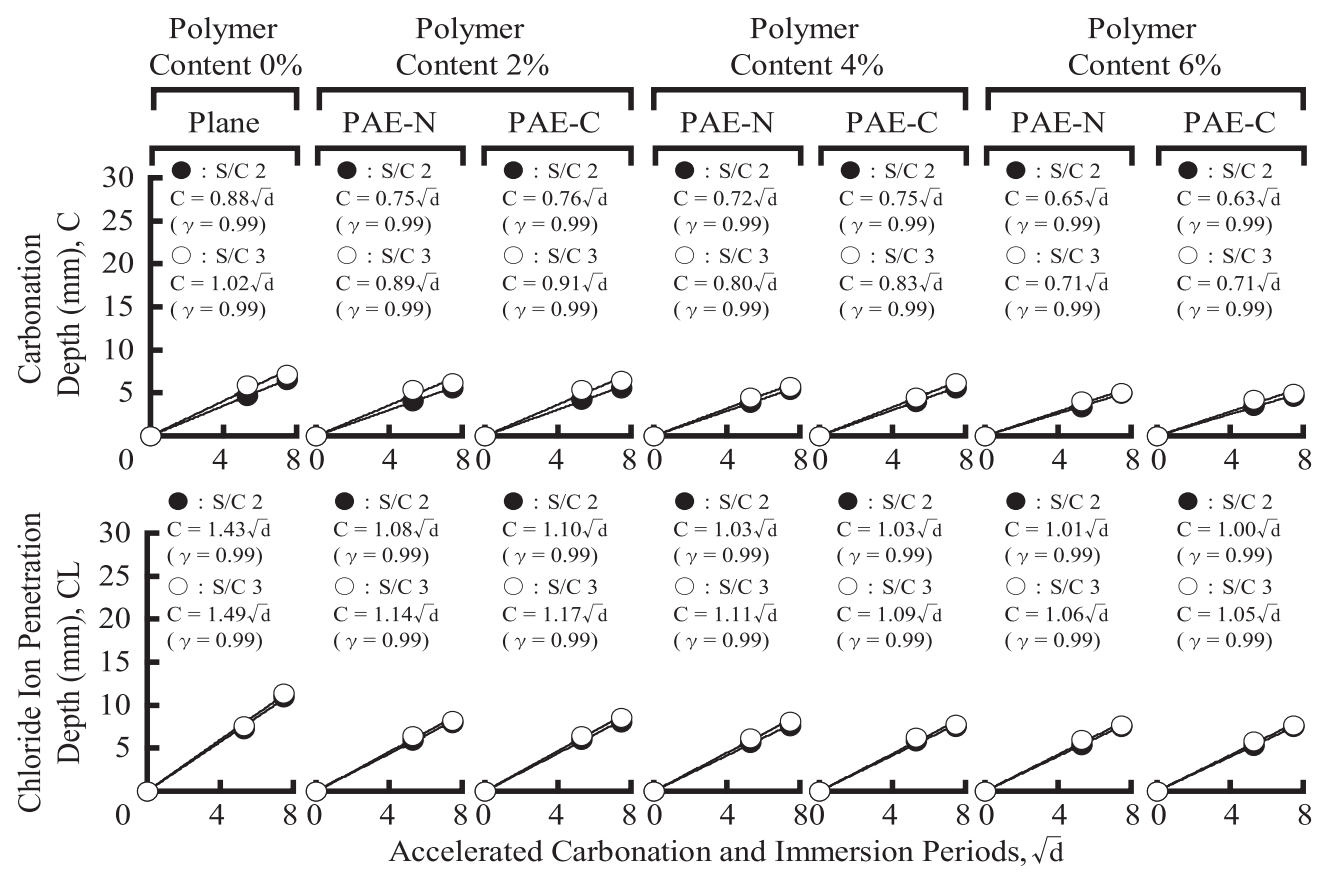

Fig. 6 Accelerated Carbonation and Immersion Periods vs. Carbonation Depth and Chloride Ion Penetration Depth of Polymer-Modified Mortars Cured by $2 \mathrm{dM}+5 \mathrm{dW}+21 \mathrm{dD}$

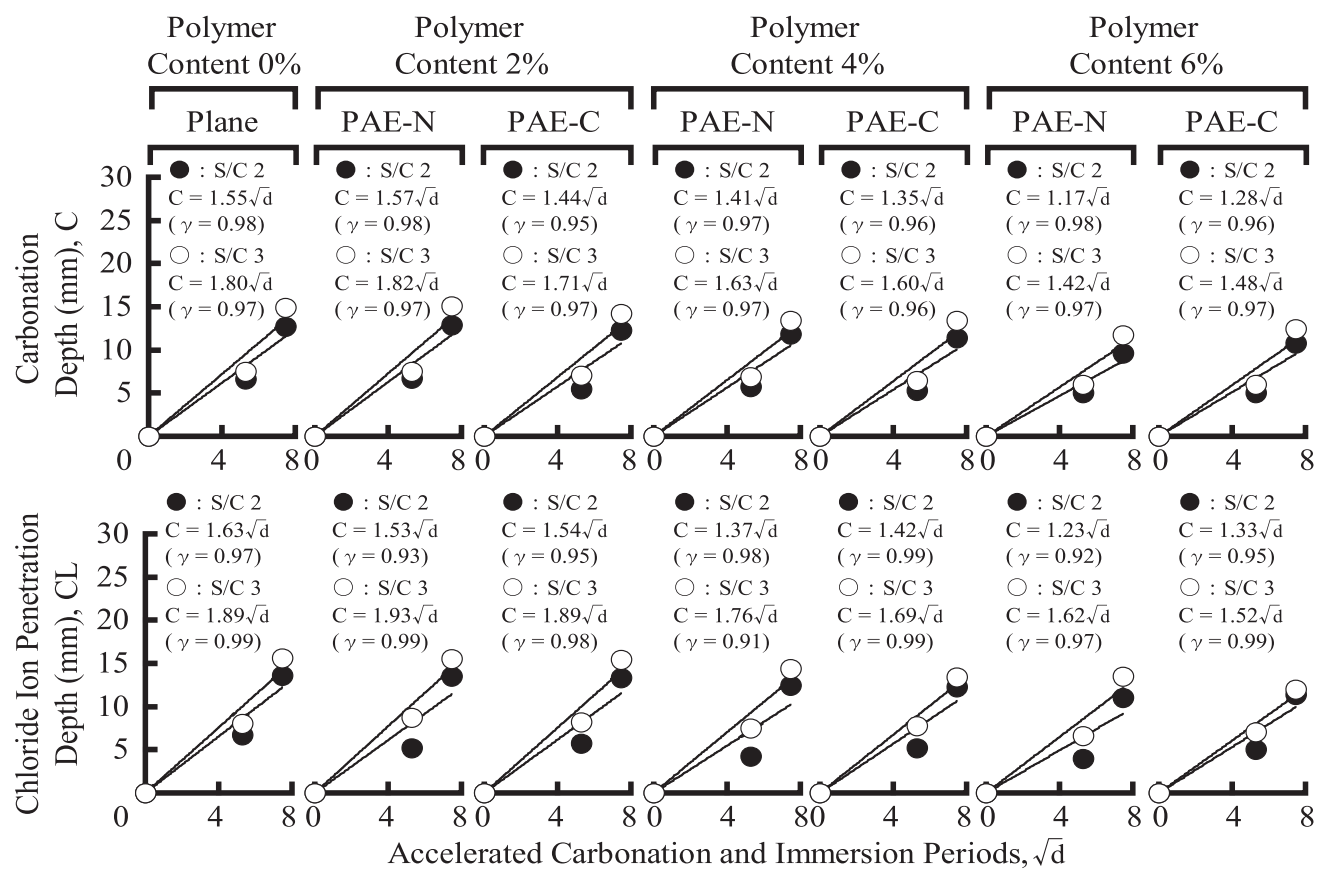

Fig. 7 Accelerated Carbonation and Immersion Periods vs. Carbonation Depth and Chloride Ion Penetration Depth of Polymer-Modified Mortars Cured by $2 \mathrm{dM}+26 \mathrm{dD}$ 


$$
\begin{aligned}
& C \text { 又は } C L=A \sqrt{t} \\
& \text { ここに、C : 中性化深さ }(\mathrm{mm}) \\
& C L: \text { 塩化物イオン浸透深さ }(\mathrm{mm}) \\
& t: \text { 試験期間 }(\mathrm{d}) \\
& A: \text { 実験定数 }
\end{aligned}
$$

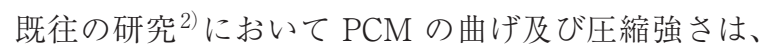
ポリマー未混入モルタルの曲げ及び圧縮強さと次に示す 影響因子の積の関数として表すことができることを報告 している。

（1）曲げ強さ影響因子

$$
S_{f}=(1-W / C)\left(1+4 V_{p}\right)\left(1-V_{a}\right)\left(1+5 V_{s}\right)
$$

(2) 圧縮強さ影響因子

$$
\begin{gathered}
S_{c}=(1-W / C)\left(1-6 V_{p}\right)\left(1-V_{a}\right) /\left(1+5 V_{s}\right) \\
\text { ここに、 } S_{f}: \text { 曲げ強さ影響因子 } \\
S_{c}: \text { 圧縮強さ影響因子 } \\
W / C: \text { 水セメント比 }(\%) \\
V_{p}: \text { ポリマーの体積分率 }(\%) \\
V_{a}: \text { 空気の体積分率 }(\%) \\
V_{s}: \text { 細骨材の体積分率 }(\%)
\end{gathered}
$$

なお、曲げ及び圧縮強さ影響因子とは、ポリマー未混 入モルタルの性能を基準とした場合、ポリマーの混入に よって、その性能がどのように変化するかを表す係数 である。そこで、ポリマー未混入モルタルの性能值を 1 とした場合、PCM の水セメント比 $(W / C)$ 並びにポリ マー、空気及び細骨材の体積分率 (それぞれ $V_{p} 、 V_{a}$ 及 び $\left.V_{s}\right)$ がその性能值に及ぼす影響を個別に回帰分析し た。その結果、 (1) S C が大きい PCM は、曲げ強さが 大きいが圧縮強さは小さく、(2)水セメント比が小さい ほど PCM の強さは優れ、(3)ポリマー混入率が増大する と PCM の曲げ強さは増大するが、圧縮強さは減少し、 (4) S/C の大小が PCM に及ぼす影響は曲げ及び圧縮強 さで逆の傾向を示すことを考慮して、式[3]及び[4]を組 み立てた。

本研究においては、PCM の性状に及ぼすポリマーの 混入効果のみを評価指標とするために、水セメント比、
空気の体積分率及び細骨材体積分率の項はこれらの式と 同様として、次のような PCM の透水量、中性化深さ及 び塩化物イオン浸透深さ影響因子の算出式を導いた。

$$
\begin{gathered}
F_{w}=(1-W / C)\left(1-8 V_{p}\right)\left(1-V_{a}\right)\left(1+5 V_{s}\right) \quad[5] \\
F_{c}=(1-W / C)\left(1-6 V_{p}\right)\left(1-V_{a}\right)\left(1+5 V_{s}\right) \quad[6] \\
F_{c l}=(1-W / C)\left(1-4 V_{p}\right)\left(1-V_{a}\right)\left(1+5 V_{s}\right) \quad[7] \\
\text { ここに、 } F_{w}: \text { 透水量影響因子 } \\
F_{c}: \text { 中性化深さ影響因子 } \\
F_{c l}: \text { 塩化物イオン浸透深さ影響因子 } \\
W / C: \text { 水セメント比 }(\%) \\
V_{p}: \text { ポリマー混入率 }(\%) \\
V_{a}: \text { 空気の体積分率 }(\%) \\
V_{s}: \text { 細骨材の体積分率 }(\%)
\end{gathered}
$$

Fig. 8 から Fig. 10 には「ポリマーセメントモルタル と同一の $\mathrm{S} / \mathrm{C}$ 及び W/C を持つポリマー未混入モルタ ルの透水量 $\left(W_{0}\right)$ 、中性化深さ $\left(C_{0}\right)$ 及び塩化物イオン浸 透深さ $\left(C l_{0}\right)$ と、式 $[5]$ から $[7] て ゙$ 算出される透水量、中 性化深さ及び塩化物イオン浸透深さ影響因子との積」と $\lceil\mathrm{PCM}$ の透水量、中性化深さ及び塩化物イオン浸透深さ」 との関係を示す。セメント混和用ポリマーの種類及び養 生条件にかかわらず、それらの間には高い相関性が認め られ、本研究の限りでは PCM の透水量、中性化深さ及 び塩化物イオン浸透深さ推定式として、次の一般式が提 案できる。

$$
\begin{aligned}
& W_{p}=A\left(W_{0} \cdot F_{w}\right)+B \\
& C_{p}=C\left(C_{0} \cdot F_{c}\right)+D \\
& C l_{p}=E\left(C l_{0} \cdot F_{c l}\right)+F \\
& \text { ここに、 } W_{p} 、 C_{p} 、 C l_{p} \text { ：それぞれ PCM の透水量 }(\mathrm{g}) 、
\end{aligned}
$$
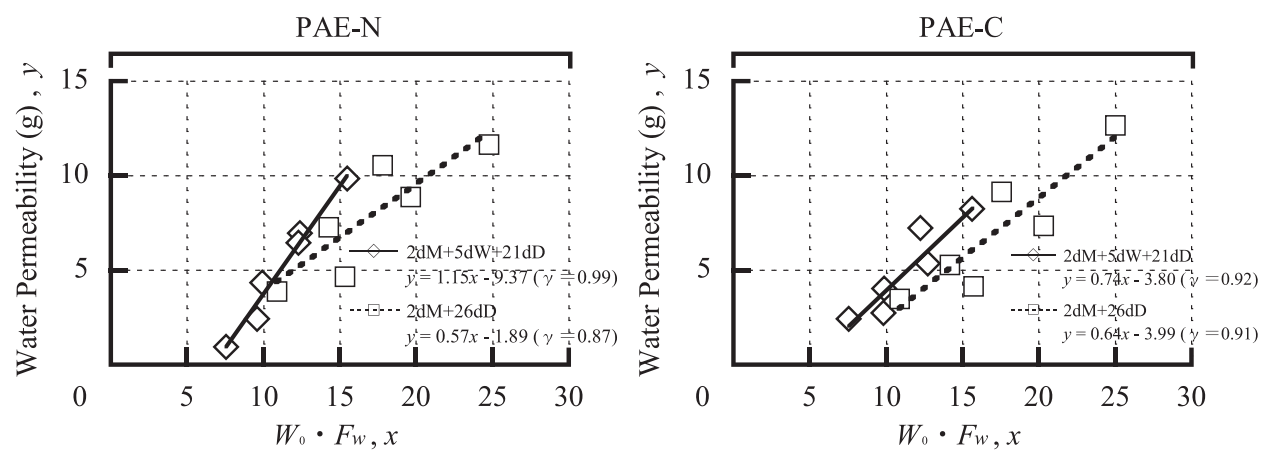

Fig. 8 Water Permeability of Polymer-Modified Mortars vs. Water Permeability Effective Factor to Unmodified Mortar 

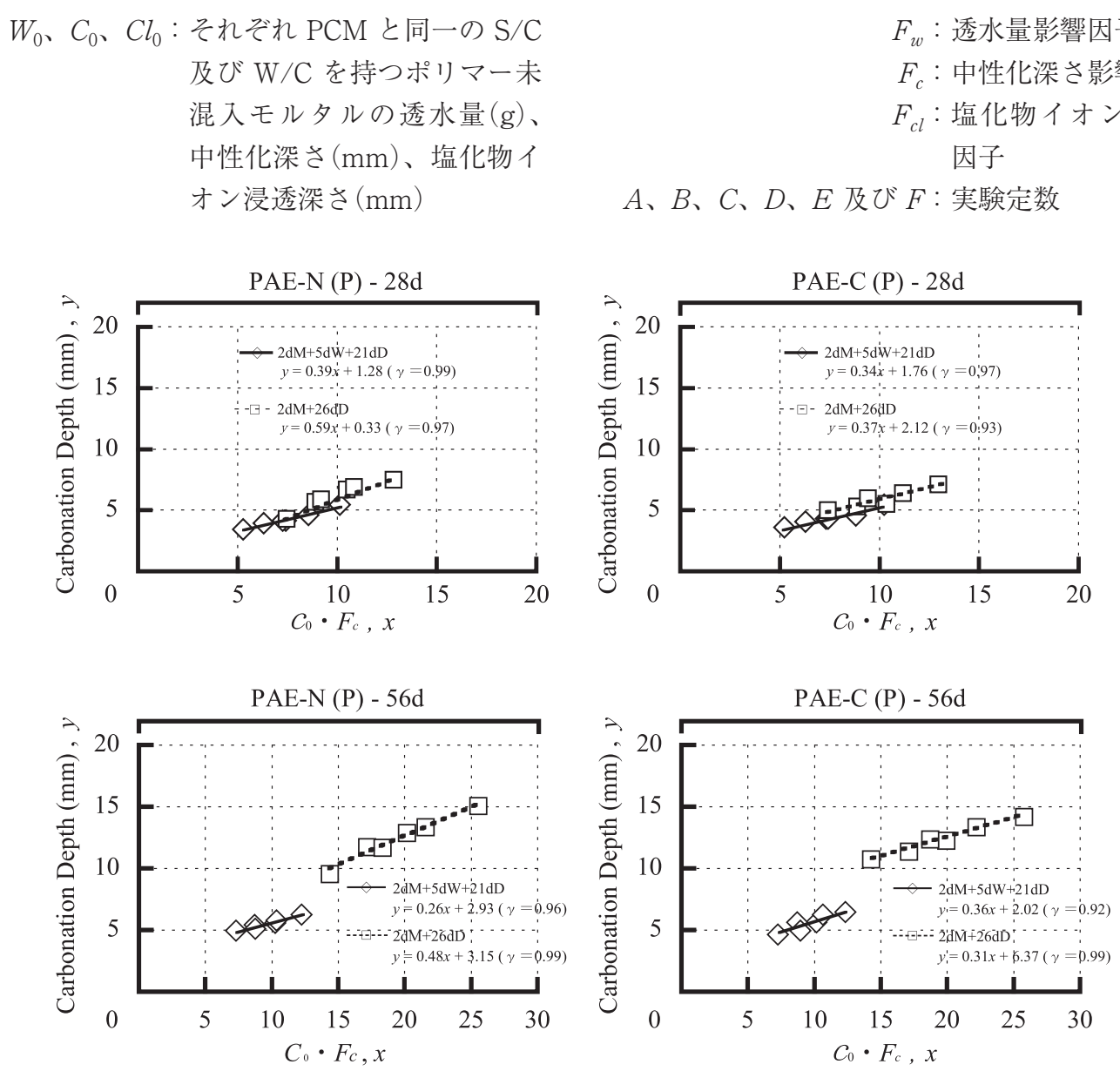

Fig. 9 Carbonation Depth of Polymer-Modified Mortars vs. Carbonation Depth Effective Factor to Unmodified Mortar
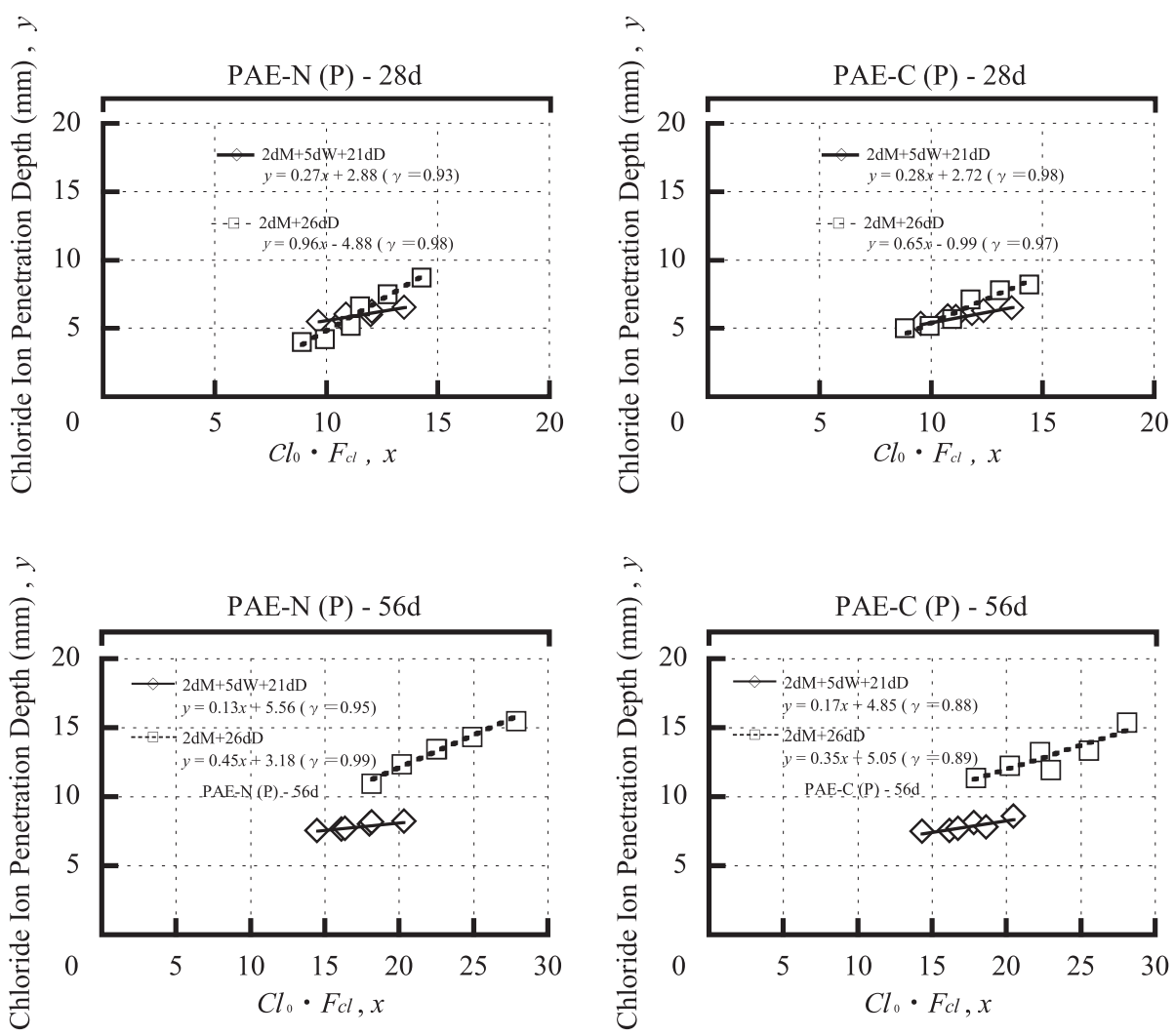

Fig. 10 Chloride lon Penetration Depth of Polymer-Modified Mortars vs. Chloride Ion Penetration Depth Effective Factor to Unmodified Mortar 
なお、PCM の透水量、中性化深さ及び塩化物イオン 浸透深さは、浸入因子としての水、 $\mathrm{CO}_{2}$ 及び塩化物イ オンに対する PCM 中のポリマー連続相のバリア効果に 依存するものである。従って、式[5]から式[7]のポリ マー混入率の項における $V_{p}$ の係数が小さいほど、浸入 因子に対するポリマー連続相のバリア効果が優れている ことを示唆するものと考える。

\section{5. 結論}

本研究の結果を結論づければ次の通りである。

（1）セメント混和用ポリマーの種類及び養生条件にかか わらず、ポリマーセメント比の増加に伴って PCM の透水量、中性化深さ及び塩化物イオン浸透深さは 減少する傾向にある。

（2）養生条件及びポリマー混入率にかかわらず、S/C 2 の $\mathrm{PCM}$ に比べて $\mathrm{S} / \mathrm{C} 3$ のものの透水量、中性化 深さ及び塩化物イオン浸透深さは若干大きい傾向に ある。しかし、ポリマー混入率の増加に伴うそれら の低減の程度は、S/Cにかかわらずほほ同様の傾 向にある。

（3） PCM の中性化深さ及び塩化物イオン浸透深さと促 進中性化及び塩化物イオン浸透試験期間の関係は 式[2]に示す $\sqrt{t}$ 則で表すことができる。

（4） PCM の透水量、中性化深さ及び塩化物イオン浸透 深さ影響因子として、水セメント比、ポリマー、空 気及び細骨材の体積分率を変数とする式 $[5]$ 、 [6]及 び式[7]が提案できる。
（5） PCM と同一の $\mathrm{S} / \mathrm{C}$ 及び $\mathrm{W} / \mathrm{C}$ を持つ、基材として のポリマー未混入モルタルの透水量、中性化深さ及 び塩化物イオン浸透深さにそれらの影響因子を乗じ て得られる積と、PCM の透水量、中性化深さ及び 塩化物イオン浸透深さの間には高い相関性が認めら れる、ポリマー混入率を PCM の新規な調合要因と して取り扱う。

（6）以上のことから、S/C にかかわらず基材となるポ リマー未混入モルタルの透水量、中性化深さ及び塩 化物イオン浸透深さが把握できれば、提案したそれ らの影響因子を用いて、PCM の透水量及び耐久性 に及ぼすセメント混和用ポリマーの混和の影響を一 義的に把握することができるものと推察される。

\section{謝辞：}

本研究は西田電君 [現清水建設 (株) ] が日本大学大学院 工学研究科博士前期課程在籍中に行った研究の成果であ り、ここに記して謝意を表する。

\section{参考文献：}

1）我喜屋宗満、齋藤俊克、出村克宣：単位ポリマー 量がポリマーセメントモルタルの吸水及び強さ性 状におよぼす影響、コンクリート工学年次論文集、 Vol. 38、No. 1、pp. 1521-1526 (2016)

2) 西田電ほか：ポリマーセメントモルタルの曲げ及び 圧縮強さに及ぼすポリマー混入率の影響、セメント・ コンクリート論文集、Vol. 72、pp. 99-105（2018） 


\title{
EFFECT OF POLYMER CONTENT ON RESISTANCE TO WATER PERMEATION AND DURABILITY OF POLYMER- MODIFIED MORTARS
}

\author{
Katsunori DEMURA*1, Toshikatsu SAITO*1 and Masaya TAKEDA*2 \\ *1 NIHON UNIVERSITY, Department of Architecture, College of Engineering (1, Nakagawara, \\ Tokusada, Tamura-machi, Koriyama-shi, Fukushima 963-8642, Japan) \\ *2 NIHON UNIVERSITY, Architecture Course, Graduate School of Engineering (1, Nakagawara, \\ Tokusada, Tamura-machi, Koriyama-shi, Fukushima 963-8642, Japan)
}

\begin{abstract}
The purpose of this study is to investigate the effect of polymer content on resistance to water permeation and durability of polymer-modified mortars. Polymer-modified mortars using re-dispersible polymer powder and with fine aggregate cement ratio of 2 and 3 , water-cement ratios of 45, 50, 55 and $60 \%$, polymer contents of $0,2,4$ and $6 \%$ are prepared, and cured under $2 \mathrm{~d}$-wet $+5 \mathrm{~d}$-water $+21 \mathrm{~d}-\mathrm{dry}$ or $2 \mathrm{~d}-$ wet $+26 \mathrm{~d}-\mathrm{dry}$ condition. Cured specimens are tested for water permeability, carbonation depth and chloride ion penetration depth. As a result, effective factors consist of water cement ratio, polymer content, air content and fine aggregate cement ratio water for the permeability, carbonation depth and chloride ion penetration depth of the polymer-modified mortar are proposed. Regardless of the type of polymer and curing condition, the good relationships are recognized for the water permeability, carbonation depth and chloride ion penetration depth of the polymer-modified mortars and the products of the those effective factors by the water permeability, carbonation depth and chloride ion penetration depth of unmodified mortar. The polymer content may be used as a new mix proportioning factor of the polymer-modified mortars.
\end{abstract}

KEY WORDS : Polymer-modified mortar, Polymer content, Water permeability, Carbonation depth, Chloride ion penetration depth, Effective factor, Estimating equation 